\title{
Domestic work stress and self-rated psychological health among women: a cross-sectional study in Japan
}

\author{
Eri Maeda ${ }^{{ }^{*}}$ (D, Kyoko Nomura ${ }^{1}$, Osamu Hiraike ${ }^{2}$, Hiroki Sugimori ${ }^{3}$, Asako Kinoshita ${ }^{3}$ and Yutaka Osuga ${ }^{2}$
}

\begin{abstract}
Background: Despite the huge burden of domestic work on women in Japan, its effects on their health have been poorly investigated. We aimed to assess the association between domestic work stress and self-rated psychological health among women.

Methods: We conducted a cross-sectional survey using an online social research panel in February 2018. Participants were 2,000 women with paid work (the "workers" group) and 1,000 women without paid work (the "homemakers" group), aged between 25 and 59 years old and living with a partner. Self-rated psychological health (Mental Health and Vitality scales of the Japanese SF-36), occupational and domestic work stress (the Brief Job Stress Questionnaire), the 10-item Work-Family Conflict Scale, and sociodemographic factors were assessed.

Results: The workers had lower domestic job control and higher support from a partner and their parents than the homemakers $(p<0.001)$, whereas domestic job demand and psychological health were similar between the groups. After adjustment for the covariates using multiple linear regression models, better psychological health was significantly associated with lower domestic job demand, higher domestic job control, and having a young child in both groups. In addition, work-family conflicts and occupational job stress among the workers and caregiving among the homemakers showed negative associations with psychological health.

Conclusion: Self-rated psychological health in women was associated with domestic work stress regardless of employment status. To promote women's health, we need to take into account the effects of domestic work, work-family conflicts, and social support from families, as well as occupational factors.
\end{abstract}

Keywords: Domestic work, Job strain, Demand-control-support model, Gender equity, WAFCS-J

\section{Introduction}

A growing number of women have joined the labor force in many countries over the past few decades. In Japan, the employment rate of women aged between 25 and 44 years has markedly increased from 57\% in 1986 to $73 \%$ in 2016 [1]. In contrast, time spent in unpaid work for men has stayed extremely low (40.8 min per day) compared to that of the most advanced country with active participation of men in housework and childrearing (e.g., $171 \mathrm{~min}$ per day in Sweden) [2]. Even among married couples with small children, the average time spent for

\footnotetext{
* Correspondence: erimaeda@med.akita-u.ac.jp

${ }^{1}$ Department of Environmental Health Science and Public Health, Akita

University Graduate School of Medicine, Akita, Japan

Full list of author information is available at the end of the article
}

domestic work per day was only 83 min among husbands, which was much shorter than among wives, 454 min [1]. These results reflect the traditional gender roles of men being breadwinners and women being responsible for family that are entrenched in the Japanese mindset $[3,4]$. In addition to the unequal domestic work division, Japanese women tend to complete domestic work within the family themselves. A recent governmental survey revealed that about $97 \%$ of women had never used professional homemaker service, not only because of the expense but also due to hesitation about letting other people enter their living space [5]. Also, less than half of women own dishwashers or drying machine [5]. Furthermore, the quality of domestic work is high; a Western newspaper has reported that typical Japanese

(c) The Author(s). 2019 Open Access This article is distributed under the terms of the Creative Commons Attribution 4.0 International License (http://creativecommons.org/licenses/by/4.0/), which permits unrestricted use, distribution, and reproduction in any medium, provided you give appropriate credit to the original author(s) and the source, provide a link to the Creative Commons license, and indicate if changes were made. The Creative Commons Public Domain Dedication waiver (http://creativecommons.org/publicdomain/zero/1.0/) applies to the data made available in this article, unless otherwise stated. 
dinner consists of multiple small dishes and that packed lunches that women prepare for children are "works of art." [6] Thus, the quantity and quality of domestic work for Japanese women are likely tremendous.

In the face of a recent severe labor shortage, the government of Japan has started to make efforts to facilitate women's active participation in the labor force as a major policy issue by encouraging men's participation in domestic work and childrearing to enable women to join the workforce [7]. Women's multiple roles as wives, mothers, and/or employees generally benefit their health by providing broad social networks, financial security, and self-esteem [8-10]. At the same time, liability related to domestic and occupational work has been conceptualized as a "double burden" [11, 12] that has significant associations with physical and mental disorders [13, 14]. A large body of literature identifies work-family conflicts [15] as a factor for adverse health outcomes among employed women [16], but few in-depth studies address the effects of domestic work itself on women's health $[17,18]$. Given the substantial amount of domestic work completed by women and differences in the nature of domestic work by culture or country $[6,19]$, we focused on domestic work stress among Japanese women, applying methods commonly used in occupational health evaluation, such as the job demand-control-support (DCS) model [20-23]. This approach may reveal the extent to which individual factors associated with domestic work affects selfperceived health.

Hence, our aim in this study was to investigate the relationship between stress associated with unpaid work at home and self-rated psychological health status of women living with a partner in Japan. Based on a previous study in Sweden [18], which first applied the demand-control model [24] to domestic work, we hypothesized that a domestic DCS model [21] would show the independent association of domestic work with psychological health even after adjusting for occupational factors, work-family conflicts, and sociodemographic factors in Japan. Specifically, we expected that a partner's support would contribute to better psychological health by reducing the domestic workload for women.

\section{Methods}

\section{Participants}

Participants were recruited via an online social research panel (SRP). Inclusion criteria were being a woman aged between 25 and 59 years of age and living with a partner. We included two groups: women with paid work (the "workers" group, $N=2,000$ ) and those without paid work (the "homemakers" group, $N$ $=1,000)$. An online market research company (Macromill, Tokyo, Japan), which has a nationwide SRP of more than 1 million registrants, sent prescreening emails for the inclusion criteria to 218,584 people aged 25-59 years, who were randomly selected from its registrants (Fig. 1). Of the 26,147 eligible people, 5,456 people received recruitment emails and 3,000 people completed the survey ( $55 \%$ participation rate among eligible subjects). We performed quota sampling by age-group block (i.e., 25-29, 30-39, 4049 , and 50-59 age groups), paid work hours per week (i.e., no work, $<30 \mathrm{~h}$, or $\geq 30 \mathrm{~h}$ ), and whether a person had a child or not, according to the prescreening responses. Recruitment continued until the intended number of participants in each block had been

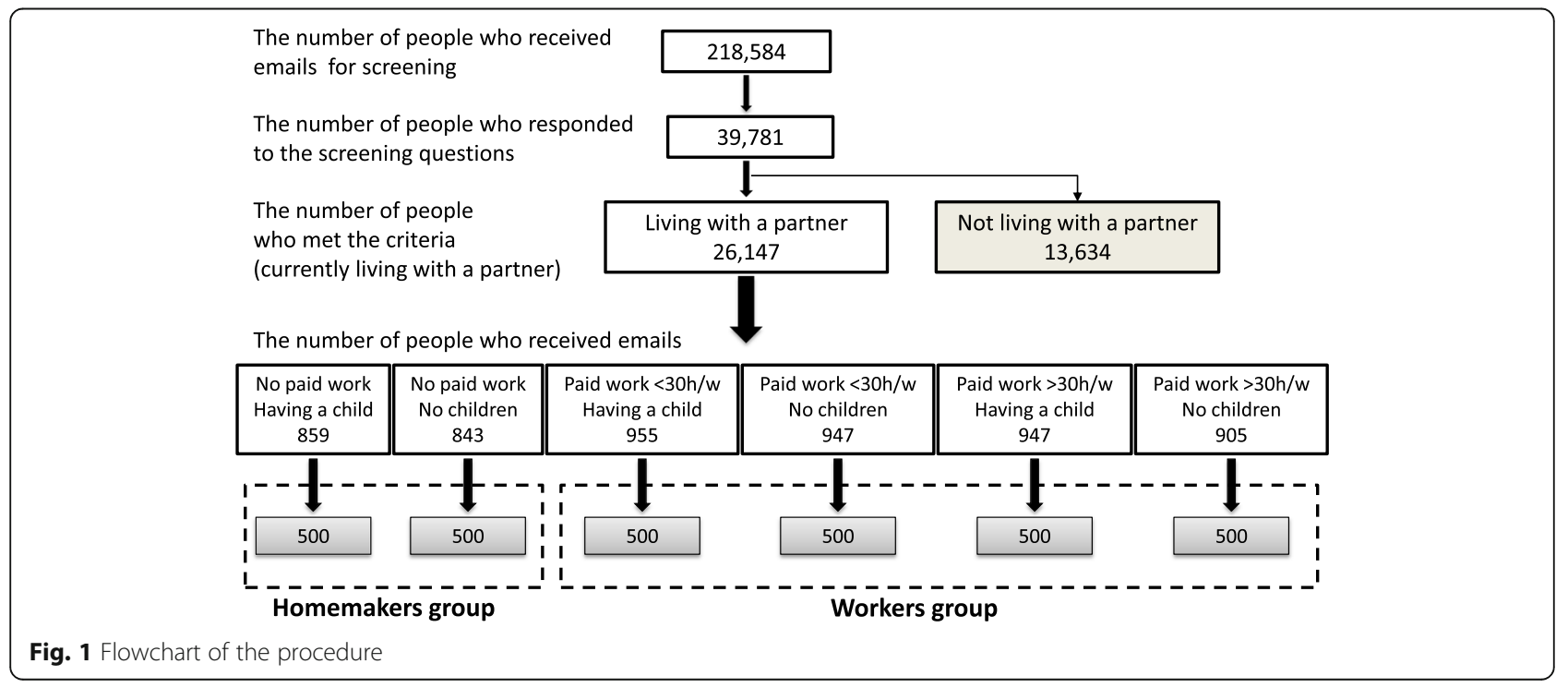


recruited. Participants were provided a reward incentive consistent with the SRP procedure. All the procedures were completed from February 20 to 25, 2018.

\section{Measures}

We developed a questionnaire to investigate the factors associated with women's health in Japan. We conducted a pilot test of the survey with a small group of our female colleagues to ensure that the questionnaire was understandable.

\section{Self-rated psychological health}

To measure psychological health of the participants, we used mental health and vitality scales of the Japanese SF36 , which were confirmed to be the best psychological health measures of the eight scales in the SF-36 in Japan [25]. The norm-based score (range 0-100) of each scale was calculated, standardizing scores to a normalized mean of 50 and standard deviation of 10, using population norms. Higher scores indicate better health-related quality of life.

\section{Occupational factors}

We used the Brief Job Stress Questionnaire (BJSQ) [26] to evaluate job demand, job control, supervisor support, and coworker support for the workers group based on the DCS model [21]. The BJSQ has been widely used for occupational health and research in Japan [23, 27, 28]. Job demand consisted of three items: (i) you have to do an enormous amount of work; (ii) you cannot complete all your work in the allotted time; and (iii) you have to work very hard. Job control included three items: (i) you can work at your own pace; (ii) you can decide the order in which you do your work and the way you do it; and (iii) you can provide your opinions on the work strategy of your workplace. Supervisor support and coworker support were evaluated with the following items: (i) you can often communicate with supervisors/coworkers; (ii) you can strongly rely on supervisors/coworkers when you have problems; and (iii) your supervisors/coworkers are prepared to spend their time on your personal problems. Participants rated their level of agreement for each item on a 4-point scale from 1 (strongly disagree) to 4 (strongly agree). A higher summed score for each dimension (range 312) indicates higher job demand, more job control, higher supervisors' support, or higher coworkers' support. In addition, we included paid work hours per week in occupational factors.

\section{Domestic work factors}

We applied the DCS model [21] to the measurement of domestic work stress. All the participants scored domestic work demand (three items with corresponding wordings to job demand measured with the BJSQ) and domestic work control (three items with corresponding wordings to job control measured with the BJSQ) on a 4-point scale from 1 (strongly disagree) to 4 (strongly agree). With regard to domestic work support, participants rated the level of support from a partner and parents or parents-in-law with a 4-point scale from 1 (poor support) to 4 (excellent support), instead of direct application of the job support items on the BJSQ. We dichotomized the level of supports: low ( 1 or 2 ) or high (3 or 4 ). In addition, we included as domestic work factors whether they provided care for any of their family members (i.e., unpaid caregiving, yes/no) and whether they had a young child ( $\leq 12$ years old, yes/no).

\section{Work-family conflict}

The Work-Family Conflict Scale (WAFCS) is a brief 10item scale of work-family conflict comprising two subscales: work-to-family conflict (WFC, five items) and family-to-work conflict (FWC, five items) [29]. Participants in the workers group were asked to rate their level of agreement for each item with a 7-point scale from 1 (very strongly disagree) to 7 (very strongly agree). Scores are reported as sums of the points, providing the total WFC score (range 7-35) and FWC score (range 7-35). Higher scores indicate higher levels of conflict. Both subscales had good internal consistency $(>0.90)$ and construct validity, as well as concurrent and predictive validity [29]. The WAFCS, originally developed to examine work-family conflict in parents of young children, has been applied to a variety of participants by defining "family" from the participant's perspective [30].

We developed the Japanese version of the WAFCS (WAFCS-J) using forward translation and back translation of the original WAFCS. Two professional translators conducted forward translations separately, and two Japanese public health researchers (EM and HS) merged two translations into one. A bilingual Japanese-English individual translated the resulting questionnaire back into English. We confirmed the concordance between the back-translated items and the originals after minor changes were made, in line with discussion between the Japanese researcher (EM) and the developer of the original WAFCS [29]. To evaluate reliability and validity of the WAFCS-J, we calculated internal consistency coefficient alpha (coefficient alpha $=0.85$ for WFC and 0.89 for FWC) and conducted a factor analysis with promax rotation (Table 4 in Appendix). The eigenvalues of the factors were 4.95 and 1.01 (> 1.0, the Kaiser's criteria of eigenvalues) [31], which accounted for $86 \%$ and $18 \%$ of 
the variance, respectively. All the items had high factor loadings after promax rotation $(\geq 0.40)$ [32] on the designated factors. Thus, the WAFCS-J appeared to have a two-factor structure and good internal consistency, as did the original WAFCS.

\section{Sociodemographic factors}

Age in years and categorized annual household income of the participants were provided by the online market research company. Annual household income was categorized into four groups: low, < 4 million Japanese Yen (JPY); moderate, 4-7 million JPY; high, $\geq 8$ million JPY; and "unknown." Participants reported their academic background (university education, yes/no).

\section{Statistical analyses}

We compared the characteristics between the workers group and the homemakers group, using Student $t$ tests, chi-square tests, and Fisher exact tests, depending on the type and distribution of the variables.

We performed the following analyses separately by groups. We compared self-rated psychological health scores between categories, using Student $t$ tests or one-way analysis of variance as appropriate. We used Pearson correlation analyses to examine the univariate association between self-rated psychological health scores and the level of job demand and control (domestic and occupational) and occupational support from supervisor and coworkers. To assess the association between self-rated psychological health and domestic work stress, we conducted multiple linear regression analyses controlling for other covariates based on previous studies [13, 14, 17, 23, 33]. We calculated the robust estimator of variance (White-corrected standard errors) [34], considering the heteroscedasticity of the variables. Additionally, we conducted subgroup analysis in the workers group by working hours per week (i.e., $<30 \mathrm{~h}$ or $\geq 30 \mathrm{~h}$ ).

A two-sided $p$ value of $<0.05$ was used to define statistical significance. All analyses were performed using Stata14-MP (StataCorp LP, College Station, TX, USA).

\section{Results}

Table 1 shows the characteristics of the two groups. Participants were about 40 years of age and of low or middle income, with about one third having a university education. In the workers group, mean working time was $30.7 \mathrm{~h}$ per week; 40 women $(2.0 \%)$ in this group reported $60 \mathrm{~h}$ or more per week. Those in the workers group were more likely to be a smoker or a habitual drinker and to have university education, higher household income, lower domestic job control, and higher support from a partner and their parents. Domestic job demand was similar between the groups.
The means \pm SD of self-rated psychological health scores of Japanese SF-36 were similar between the groups (Table 1). Univariate associations between selfrated psychological health scores and associated factors are shown in Table 2. In the workers group, the Mental Health score showed negative correlations with domestic and occupational job demand and work-family conflicts, and positive correlations with domestic and occupational job control and occupational support from supervisors and co-workers. The Mental Health score was significantly higher among participants in their 50s than among those in their 20s and was higher among participants with middle/high/unknown household income than among those with low household income. Multiple linear regression analyses showed that a higher Mental Health score was associated with lower domestic job demand, higher domestic job control, lower occupational job demand, higher occupational job control, higher occupational support from supervisors and co-workers, lower work-family conflicts, being in their 50s, having a young child, and having higher household income. Similar univariate and multivariate associations between the Vitality score and the study variables were observed. Additionally, having high support from parents or parents-in-law was positively associated with the Vitality score.

In the homemakers group (Table 2), the Mental Health score was negatively correlated with domestic job demand and positively correlated with domestic job control. The Mental Health score was significantly higher among individuals who received high support from a partner and among those who had high household income, and lower among those who provided care for a family member. Multiple linear regression analyses showed that a higher Mental Health score was associated with lower domestic job demand, higher domestic job control, having a young child, having high household income, and not providing care for a family member. Similar univariate and multivariate associations between the Vitality score and the study variables were observed. Additionally, having high support from parents or parents-in-law was positively associated with the Vitality score.

Subgroup analyses by working hours revealed that lower domestic job demand and having a young child were positively associated with psychological health, irrespective of working hours (Table 3). Higher domestic job control among short-time workers ( $<30 \mathrm{~h}$ per week) and high support from parents or parents-in-law among long-time workers ( $\geq 30 \mathrm{~h}$ per week) showed significant associations with psychological health scores, but there were no significant interactions. 
Table 1 Characteristics and self-rated psychological health of the study participants

\begin{tabular}{|c|c|c|c|}
\hline & $\begin{array}{l}\text { Workers } \\
(N=2,000)\end{array}$ & $\begin{array}{l}\text { Homemakers } \\
(N=1,000)\end{array}$ & $p$ value \\
\hline \multicolumn{4}{|l|}{ Demographics } \\
\hline Age in years, mean $\pm S D$ & $41.8 \pm 9.6$ & $41.9 \pm 9.9$ & 0.83 \\
\hline University education, $N(\%)$ & $698(34.9)$ & $304(30.4)$ & 0.01 \\
\hline Annual household income, N (\%) & & & $<0.001$ \\
\hline Low: $<4$ million JPY & $360(18.0)$ & $214(21.4)$ & \\
\hline Middle: 4-7 million JPY & $793(39.6)$ & $369(36.9)$ & \\
\hline High: $\geq 8$ million JPY & $379(19.0)$ & $134(13.4)$ & \\
\hline Unknown & $468(23.4)$ & $283(28.3)$ & \\
\hline \multicolumn{4}{|l|}{ Lifestyles } \\
\hline Current smoker, $N(\%)$ & $329(16.4)$ & $105(10.5)$ & $<0.001$ \\
\hline Habitual drinker (once a week or more), N (\%) & $605(30.2)$ & $223(22.3)$ & $<0.001$ \\
\hline \multicolumn{4}{|l|}{ Domestic work factors } \\
\hline Job demand, mean \pm SD [range: 3-12] & $7.5 \pm 1.9$ & $7.5 \pm 1.9$ & 0.95 \\
\hline Job control, mean \pm SD [range: 3-12] & $9.5 \pm 1.8$ & $9.9 \pm 1.7$ & $<0.001$ \\
\hline High support from a partner, $N(\%)^{a}$ & $765(38.2)$ & $295(29.5)$ & $<0.001$ \\
\hline High support from parents or parents-in-law, $N(\%)^{a}$ & $402(20.1)$ & $141(14.1)$ & $<0.001$ \\
\hline Having a young child, $N(\%)$ & $564(28.2)$ & $308(30.8)$ & 0.14 \\
\hline Giving care to a family member, $N(\%)$ & $96(4.8)$ & $58(5.8)$ & 0.24 \\
\hline \multicolumn{4}{|l|}{ Occupational factors } \\
\hline Job demand, mean \pm SD [range: 3-12] & $7.5 \pm 2.1$ & - & \\
\hline Job control, mean \pm SD [range: 3-12] & $8.1 \pm 2.2$ & - & \\
\hline Support from supervisors, mean \pm SD [range: 3-12] & $7.1 \pm 2.4$ & - & \\
\hline Support from co-workers, mean \pm SD [range: 3-12] & $7.8 \pm 2.4$ & - & \\
\hline Working hours per week, mean \pm SD & $30.7 \pm 14.1$ & - & \\
\hline \multicolumn{4}{|l|}{ Work-family conflicts } \\
\hline Work-to-family conflicts, median (IQR) [range: 5-35] & $16(10-20)$ & - & \\
\hline Family-to-work conflict, median (IQR) [range: 5-35] & $10(5-16)$ & - & \\
\hline \multicolumn{4}{|l|}{ Self-rated psychological health on the SF-36 } \\
\hline Mental Health score & $46.3 \pm 10.1$ & $46.6 \pm 10.7$ & 0.45 \\
\hline Vitality score & $44.8 \pm 10.2$ & $45.4 \pm 10.5$ & 0.10 \\
\hline
\end{tabular}

$p$ values were calculated by Student $t$ test for continuous variables and chi-square tests for categorical variables $\mathrm{IQR}$, interquartile range

${ }^{a}$ Those who received excellent or good support

\section{Discussion}

This quantitative study conducted in Japan is the first to demonstrate the independent relationship between domestic work stress and self-rated psychological health in Japan. We confirmed that higher domestic job demand and lower domestic job control are significantly associated with poorer self-rated psychological health both in the workers group and in the homemakers group. Similar regression coefficients of domestic and occupational job stress in the workers group suggest the importance of accounting for domestic factors when encouraging women to work in society. Based on the fact that the proportion of households with full-time homemakers is declining but still $38 \%$ in Japan [1], determining the domestic work stress for homemakers is important, particularly since their health has not received much attention in the past. In addition, we found no significant association between partners' support and psychological health even after adjusting for covariates, whereas having a child or support from parents/parents-in-law showed positive associations with self-rated psychological health. 


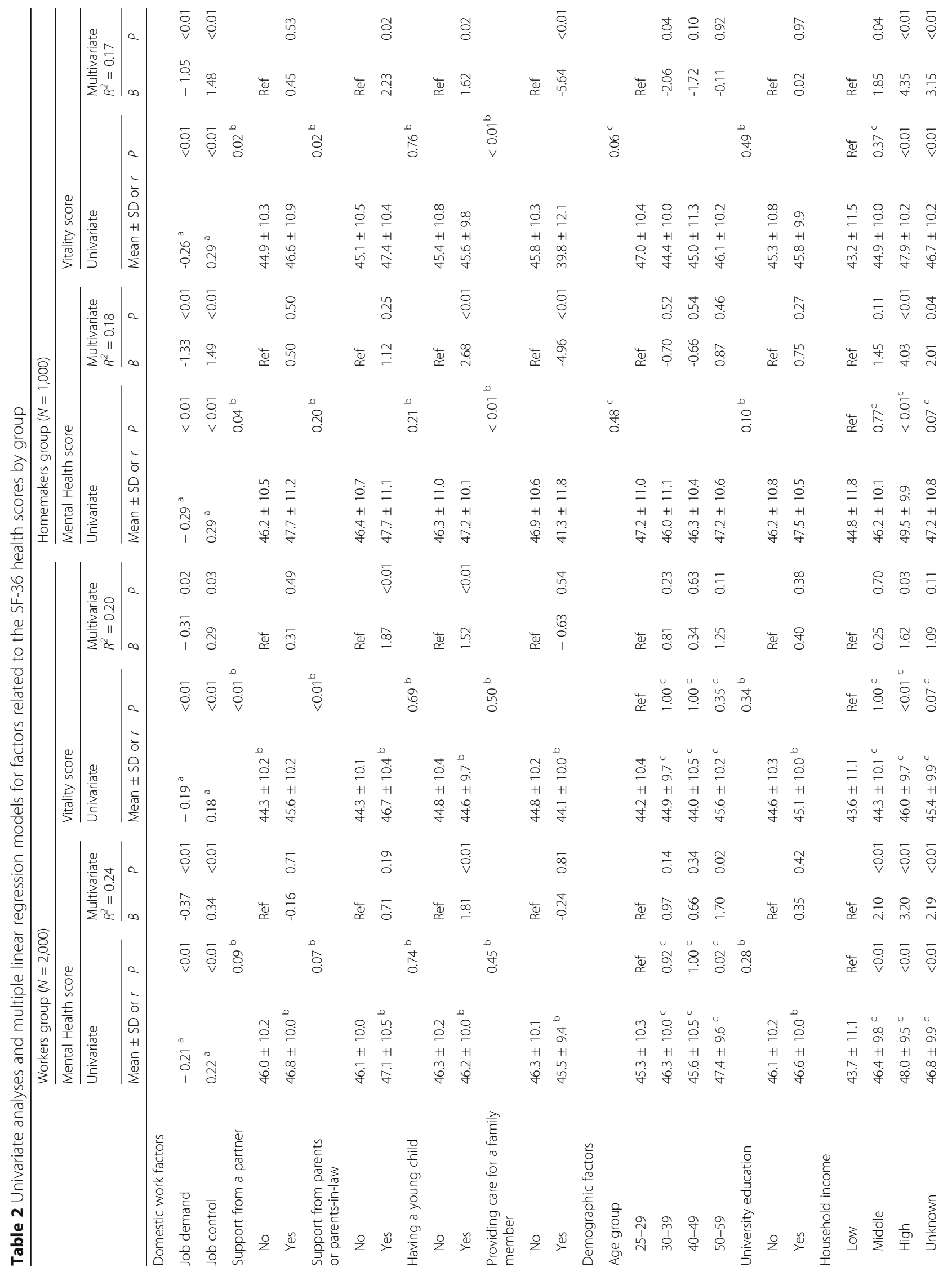




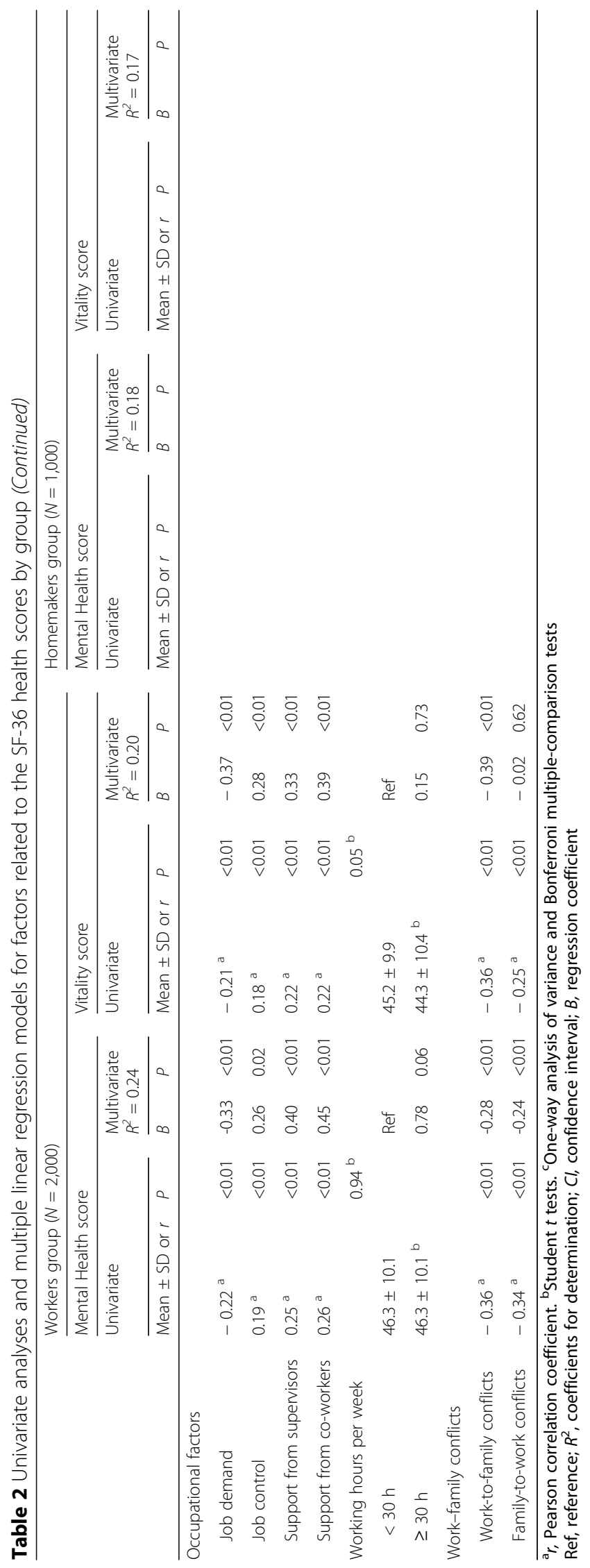


Table 3 Subgroup analyses of regression coefficient $B^{\text {a }}$ for domestic work factors to self-rated mental health by working hours

\begin{tabular}{|c|c|c|c|c|c|c|c|c|}
\hline & \multicolumn{4}{|c|}{$<30$ h per week $(N=1,000)$} & \multicolumn{4}{|c|}{$\geq 30$ h per week $(N=1,000)$} \\
\hline & \multicolumn{2}{|c|}{ Mental Health score } & \multicolumn{2}{|c|}{ Vitality score } & \multicolumn{2}{|c|}{ Mental Health score } & \multicolumn{2}{|c|}{ Vitality score } \\
\hline & $B$ & $P$ & $B$ & $P$ & $B$ & $P$ & $B$ & $P$ \\
\hline Domestic job demand (each additional point higher) & -0.42 & 0.03 & -0.31 & 0.10 & -0.35 & 0.04 & -0.32 & 0.09 \\
\hline Domestic job control (each additional point higher) & 0.41 & 0.03 & 0.38 & 0.04 & 0.24 & 0.16 & 0.18 & 0.35 \\
\hline High support from a partner & 0.001 & 0.99 & 0.54 & 0.41 & -0.24 & 0.67 & 0.16 & 0.80 \\
\hline High support from parents or parents-in-law & 0.06 & 0.94 & 0.97 & 0.22 & 1.23 & 0.09 & 2.64 & $<0.01$ \\
\hline Having a young child & 2.22 & $<0.01$ & 1.35 & 0.06 & 1.50 & 0.04 & 1.77 & 0.02 \\
\hline Giving care to a family member & 0.31 & 0.84 & -0.82 & 0.57 & -0.92 & 0.48 & -0.47 & 0.75 \\
\hline
\end{tabular}

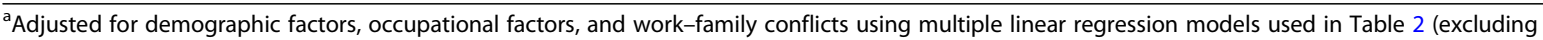
working hours)

Negative associations between domestic workload and self-rated psychological health are consistent with previous studies. A higher domestic workload was reported to be associated with increased psychological distress [14, 35, 36], suboptimal self-rated health [17], and cardiovascular health risks [13, 37]. However, previous studies assessed domestic workload using a variety of indicators, such as domestic working hours $[11,12,17,36,37]$, the unequal division of domestic work [14, 33, 35], subjective burden [17], and the factors constituting domestic work (e.g., childcare, living with the elderly) [13, 38]. Because each individual would define their own domestic work differently in terms of quality and quantity [19], we applied the DCS model [21] as a means to determine subjective domestic workload, and we confirmed the findings from the previous Swedish study [18]. Given these results and the lack of validated scales for domestic workload, applying the DCS model to domestic work is a promising method to quantify the psychological stress associated with domestic work among women. However, significant associations between domestic job control and psychological health were not found among women working for $30 \mathrm{~h}$ or more (Table 3), whereas domestic job demand consistently showed significantly negative associations with self-rated psychological health. We speculate that full-time workers might have a different view of domestic work, such as not giving importance to feeling in control of domestic work. Identifying factors and items contributing to high domestic job demand and low domestic job control would be an area for future research.

We did not detect significant associations between support from a partner and self-rated psychological health when we adjusted for covariates. Our analytical models confirmed that no collinearity existed between support from a partner/parents and having a child. Previously, marriage or support from a partner was shown to be a protective factor for overall subjective health of women [39]. Alternatively, the literature suggests that unequal division of domestic work and family responsibility is associated with less life satisfaction, poor self-rated health [40], and perceived physical/psychosomatic symptoms [14]. In this regard, the insignificant effect of support from a partner in the present study could be due to the study design; we excluded potential participants who had been divorced or were living separately, which might have decreased the statistical power to detect significant differences.

On the other hand, the insignificant results regarding support from a partner could illustrate the characteristics of married couples in Japan. First, the present participants might not have expected their partner to do much domestic work. Previous studies showed that women in societies in which traditional gender roles are followed did not recognize the unequal division of domestic work as an unfair situation [41]. Indeed, a fairly high percentage of the participants rated the level of support from a partner as "good" or "excellent" (35\%, Table 1), in comparison with the national surveys indicating that men have extremely little unpaid work time [1]. Second, some support provided by a partner might not be sufficient to increase the level of satisfaction (i.e., psychological health) compared to the amount of domestic work routinely provided by women. Based on previous works showing higher mortality rates and riskpromoting dietary habits among unmarried men [42] and men living apart from their wives [43], men would directly benefit from their wives through the receipt of domestic work as well as social support. In contrast, mismatches between women's expectation and domestic work actually completed by men have been pointed out [44]. To decrease domestic job stress, both wives and husbands are encouraged to 
remove traditional gender roles at home; in addition, discussing the social norms for domestic work and redefining them are necessary steps because the quantity and quality of the work have been determined by social, cultural, emotional, and environmental contexts [19]. It should be acknowledged that the idea of domestic work done to perfection held in the minds of Japanese women $[6,44]$ might have hampered the domestic participation of men and the equal division.

Having young children consistently showed positive associations with self-rated psychological health in all subgroups. Childrearing generally increases domestic workload and is known to increase the risk of poor self-rated health and fatigue among employed women, especially for those working long hours [45]. However, recent studies have shown that the presence of children, serving as a social support, had a mitigating effect on psychological burnout among academic professionals [46]. In this study, self-rated psychological health of the 628 women whose youngest child was older than 12 did not differ from that of women having no children (data not shown). This outcome could be explained by all the participants at least living with their partner and receiving some social support. Along with the positive associations between high support from parents/parents-in-law and Vitality scores, social support from families likely improves the psychological health of women.

Unpaid caregivers in the homemaker group showed significantly lower psychological health scores (Table 2). Substantial literature shows that caregivers generally report higher level of distress and depressive symptoms than non-caregiving peers [47]. At the same time, the extent of the psychological impact is affected by many factors, such as the type of disability of the recipient, the caregiver's financial situation, the quality and quantity of social support, and whether or not the caregiver lives with the recipient [47]. Although health status or disability of the recipient could have been more serious in the homemakers group than in the workers group, social support at work places, income obtained from occupational work, or the use of professional care services might have alleviated the burden of caregiving.

We confirmed negative associations between occupational job stress and psychological health (Table 2) in line with previous studies using the DCS models [23, 27]. However, no significant relationships were found between working hours and self-rated psychological health, possibly because only $2 \%$ of the present workers worked for $60 \mathrm{~h}$ or more per week. Earlier studies showed significant associations between working hours and depressive symptoms or burnout
$[23,48]$ only when the working hours exceeded $60 \mathrm{~h}$, which would be consistent with our finding of insignificant results. Multiple roles of women generally restrict their working hours as employees. According to government statistics, the proportions of Japanese men and women who work for $60 \mathrm{~h}$ or more are $11 \%$ and $2.8 \%$, respectively [49]. Occupational job demand measuring the subjective amount of work in a set period of time would be appropriate for measuring the workload of women or others who work in diverse ways [50].

Another contribution of the present study is the development of the WAFCS-J. A number of WorkFamily Conflict Scales that vary in construction (e.g., from one to six dimensions) and in length (e.g., from 2 to 22 items) have been developed [51, 52], but only a few validated scales that are brief and sensitive exist. The WAFCS, which consists of 10 items, can easily be used as a secondary indicator in surveys [29]. A strength of the WAFCS is that it could be applicable not only for parents of small children but also for a wide range of people [30] in diverse family structures and lifestyles. Along with previous reports on the adverse health outcomes of work-family conflicts $[16,53]$, the present findings (Table 2) add evidence for the need to consider work-family conflicts during routine psychological health evaluations of employees.

This study has some limitations. First, it is a crosssectional study, thus we cannot infer causality. Second, the use of an SRP could have caused selection bias. In particular, the percentage of the participants who had a university education was twice as high as that found in the 2010 Population Census (15\% in women aged between 25 and 59 years old). Therefore, generalizing our results to the national population might cause self-rated psychological health to be overestimated. However, the association between domestic workload and self-rated psychological health shown in the multivariate linear regression models would not be heavily biased.

\section{Conclusion}

Higher domestic job demand and lower domestic job control were associated with poorer self-rated psychological health among women with and without paid work in Japan. Health promotion of female workers requires consideration of the effects of domestic work, work-family conflicts, and the presence of social support from families. Future study is warranted for developing strategies to reduce domestic work stress, not only by removing the traditional gender roles at home but also by changing social norms related to domestic work. 


\section{Appendix}

Table 4 Results of the exploratory factor analysis for the Japanese version of the Work-Family Conflict Scale with promax rotation

\begin{tabular}{|c|c|c|c|c|}
\hline & & \multicolumn{2}{|c|}{ Factor loadings } & \multirow[t]{2}{*}{ Uniqueness } \\
\hline & & $\begin{array}{l}\text { Factor } 1 \\
\text { FWC } \\
a=0.89\end{array}$ & $\begin{array}{l}\text { Factor } 2 \\
\text { WFC } \\
a=0.85\end{array}$ & \\
\hline 1 & $\begin{array}{l}\text { My work prevents me spending sufficient quality time with my family } \\
\text { 仕事のせいで、家族との充実した時間を十分にとれない。 }\end{array}$ & -0.04 & 0.84 & 0.33 \\
\hline 2 & $\begin{array}{l}\text { There is no time left at the end of the day to do the things l'd like at home (e.g., chores and leisure activities) } \\
\text { 一日の終わりに、家でゃりたいこと(いろいろな用事や余㗇活動など)をする時間が残つていない。 }\end{array}$ & -0.09 & 0.70 & 0.58 \\
\hline 3 & $\begin{array}{l}\text { My family misses out because of my work commitments } \\
\text { 私が仕事に専念するので、家族がさびしがる。 }\end{array}$ & 0.17 & 0.55 & 0.55 \\
\hline 4 & $\begin{array}{l}\text { My work has a negative impact on my family life } \\
\text { 仕事が家庭生活に㯖影響を及ぼしている。 }\end{array}$ & 0.09 & 0.77 & 0.30 \\
\hline 5 & $\begin{array}{l}\text { Working often makes me irritable or short tempered at home } \\
\text { 仕事のせいで、家でイライラレたり、かつとなったりすることが多い。 }\end{array}$ & 0.11 & 0.65 & 0.50 \\
\hline 6 & $\begin{array}{l}\text { My work performance suffers because of my personal and family commitments } \\
\text { 私用や家庭の用事のために、仕事の成果が上がらない。 }\end{array}$ & 0.66 & 0.22 & 0.34 \\
\hline 7 & $\begin{array}{l}\text { Family related concerns or responsibilities often distract me at work } \\
\text { 家庭の心配事や用事のために、仕事に集中できないことが多い。 }\end{array}$ & 0.64 & 0.22 & 0.37 \\
\hline 8 & $\begin{array}{l}\text { If I did not have a family l'd be a better employee } \\
\text { 家族がいなければもつと優秀な社員になれると思う。 }\end{array}$ & 0.76 & -0.04 & 0.46 \\
\hline 9 & $\begin{array}{l}\text { My family has a negative impact on my day to day work duties } \\
\text { 家族は日タの仕事に悪影響を与えてい。 }\end{array}$ & 0.89 & -0.12 & 0.31 \\
\hline 10 & $\begin{array}{l}\text { It is difficult to concentrate at work because I am so exhausted by family responsibilities } \\
\text { 家のことで疲れ果てて仕事に集中するのが難しい。 }\end{array}$ & 0.79 & 0.07 & 0.30 \\
\hline
\end{tabular}

Factor loadings $\geq 0.40$ are in bold

FWC family-to-work conflict; WFC work-to-family conflict; $a$ Cronbach coefficient alpha

\section{Acknowledgements}

The authors thank Ms. Junko Hirayama for her assistance in data analyses.

\section{Authors' contribution}

EM contributed to the conception and design of the study, the acquisition of data and analysis, and the interpretation of data; drafted all versions of the article; and approved the final version for publication. $\mathrm{KN}, \mathrm{OH}, \mathrm{HS}, \mathrm{AK}$, and $\mathrm{YO}$ contributed to the analysis and interpretation of data, all revisions, and the final approval for publication.

\section{Funding}

This work was supported by Health and Labour Sciences Research Grants(H29-Josei-Ippan-001 and 19FB1001)

\section{Availability of data and materials}

The datasets generated and/or analyzed during the current study are not publicly available due to including the privacy of the participants but are available from the corresponding author on reasonable request.

\section{Ethics approval and consent to participate}

The ethics committee at Akita University Graduate School of Medicine approved the study protocol (no. 1905, approved on February 15, 2018). Collection of online data complied with the "Code of Conduct of Marketing Research" and "Requirements for Compliance Program on Personal Information Protection (JIS Q 15001)" of the Japan Marketing Research Association.

\section{Consent for publication}

Not applicable.

\section{Competing interests}

The authors declare that they have no competing interests.

\section{Author details}

${ }^{1}$ Department of Environmental Health Science and Public Health, Akita University Graduate School of Medicine, Akita, Japan. ${ }^{2}$ Department of Obstetrics and Gynecology, Graduate School of Medicine, The University of Tokyo, Tokyo, Japan. ${ }^{3}$ Department of Preventive Medicine, Graduate School of Sports and Health Sciences, Daito Bunka University, Saitama, Japan.

Received: 16 September 2019 Accepted: 25 November 2019 Published online: 17 December 2019

\section{References}

1. Ministry of Internal Affairs and Communications. Labour Force Survey. 2016.

2. Organisation for Economic Cooperation and Development. OECD.Stat. 2019. https://stats.oecd.org/index.aspx?queryid=54757 (accessed on 12 July 2019)

3. Kawase K, Nomura K, Tominaga R, Iwase H, Ogawa T, Shibasaki I, et al. Analysis of gender-based differences among surgeons in Japan: results of a survey conducted by the Japan Surgical Society. Part. 2: personal life. Surg Today. 2018:48:308-19.

4. Gender Equality Bureau Cabinet Office. Women and men in Japan 2019 . http://www.gender.go.jp/english_contents/pr_act/pub/pamphlet/womenand-men19/index.html (accessed on 12 July 2019).

5. Takeda K. Kaji shien service no genjo. Japanese Journal of Labour Studies. 2017:689:62-8.

6. Rich M. Japan's working mothers: record responsibilities, little help from dads. The New York Times. February 2, 2019. https://www.nytimes.com/201 9/02/02/world/asia/japan-working-mothers.html (accessed on 12 July 2019)

7. Government of Japan. https://www.japan.go.jp/diversity/women/index.html (accessed on 12 July 2019)

8. Lahelma E, Arber S, Kivelä K, Roos E. Multiple roles and health among British and Finnish women: the influence of socioeconomic circumstances. Soc Sci Med. 2002:54:727-40.

9. Waldron I, Weiss CC, Hughes ME. Interacting effects of multiple roles on women's health. J Health Soc Behav. 1998;39:216-36. 
10. Okada N, Yabase K, Kobayashi T, Okamura H. Do multiple personal roles promote working energetically in female nurses? A cross-sectional study of relevant factors promoting work engagement in female nurses. Environ Health Prev Med. 2019;24:56.

11. Krantz G, Berntsson L, Lundberg U. Total workload, work stress and perceived symptoms in Swedish male and female white-collar employees. Eur J Public Health. 2005;15:209-14

12. Mellner C, Krantz G, Lundberg U. Symptom reporting and self-rated health among women in mid-life: the role of work characteristics and family responsibilities. Int J Behav Med. 2006;13:1-7.

13. D'Ovidio F, d'Errico A, Scarinzi C, Costa G. Increased incidence of coronary heart disease associated with "double burden" in a cohort of Italian women. Soc Sci Med. 2015;135:40-6.

14. Eek F, Axmon A. Gender inequality at home is associated with poorer health for women. Scand J Public Health. 2015:43:176-82.

15. Greenhaus JH, Beutell NJ. Sources of conflict between work and family roles. Acad Manag Rev. 1985;10:76-88.

16. Kobayashi T, Honjo K, Eshak ES, Iso H, Sawada N, Tsugane S, et al. Workfamily conflict and self-rated health among Japanese workers: how household income modifies associations. PLoS One. 2017;12:e0169903.

17. Molarius A, Granstrom F, Linden-Bostrom M, Elo S. Domestic work and selfrated health among women and men aged 25-64 years: results from a population-based survey in Sweden. Scand J Public Health. 2014;42:52-9.

18. Staland-Nyman C, Alexanderson K, Hensing G. Associations between strain in domestic work and self-rated health: a study of employed women in Sweden. Scand J Public Health. 2008;36:21-7.

19. Messias DK. Transnational perspectives on women's domestic work: Experiences of Brazilian immigrants in the United States. Women Health. 2001:33:1-20.

20. Inoue A, Kawakami N, Tsuno K, Shimazu A, Tomioka K, Nakanishi M. Job demands, job resources, and work engagement of Japanese employees: a prospective cohort study. Int Arch Occup Environ Health. 2013;86:441-9.

21. Johnson JV, Hall EM, Theorell T. Combined effects of job strain and social isolation on cardiovascular disease morbidity and mortality in a random sample of the Swedish male working population. Scand J Work Environ Health. 1989:15:271-9.

22. Kawada T, Otsuka T. Relationship between job stress, occupational position and job satisfaction using a brief job stress questionnaire (BJSQ). Work 2011:40:393-9.

23. Saijo Y, Yoshioka E, Kawanishi Y, Nakagi Y, Itoh T, Yoshida T. Relationships of job demand, job control, and social support on intention to leave and depressive symptoms in Japanese nurses. Ind Health. 2016;54:32-41.

24. Karasek RA Jr. Job demands, job decision latitude, and mental strain: implications for job redesign. Adm Sci Q. 1979;24:285-308.

25. Fukuhara S, Ware J, Kosinski M, Wada S, Gandek B. Psychometric and clinical tests of validity of the Japanese SF-36 Health Survey. J Clin Epidemiol. 1998; 51:1045-53.

26. Shimomitsu T. The final development of the Brief Job Stress Questionnaire mainly used for assessment of the individuals. Ministry for Labour sponsored grant for the prevention of work-related illness: The 1999 report. 2000; 126-164

27. Enoki M, Maeda E, Iwata T, Murata K. The association between work-related stress and autonomic imbalance among call center employees in Japan. Tohoku J Exp Med. 2017;243:321-8.

28. Umehara K, Ohya Y, Kawakami N, Tsutsumi A, Fujimura M. Association of work-related factors with psychosocial job stressors and psychosomatic symptoms among Japanese pediatricians. J Occup Health. 2007:49:467-81.

29. Haslam D, Filus A, Morawska A, Sanders MR, Fletcher R. The Work-Family Conflict Scale (WAFCS): development and initial validation of a self-report measure of work-family conflict for use with parents. Child Psychiatry Hum Dev. 2015;46:346-57.

30. Guille C, Frank E, Zhao Z, Kalmbach DA, Nietert PJ, Mata DA, et al. Workfamily conflict and the sex difference in depression among training physicians. JAMA Intern Med. 2017;177:1766-72.

31. Kaiser HF. The application of electronic computers to factor analysis Educational and psychological measurement. 1960;20:141-51.

32. Pett MA, Lackey NR, Sullivan JJ. Making sense of factor analysis: the use of factor analysis for instrument development in health care research: SAGE; 2003.

33. Harryson L, Strandh M, Hammarstrom A. Domestic work and psychological distress--what is the importance of relative socioeconomic position and gender inequality in the couple relationship? PLoS One. 2012;7:e38484.
34. White $\mathrm{H}$. A heteroskedasticity-consistent covariance matrix estimator and a direct test for heteroskedasticity. Econometrica. 1980;48:817-38.

35. Bird CE. Gender, household labor, and psychological distress: the impact of the amount and division of housework. J Health Soc Behav. 1999;40:32-45.

36. Glass J, Fujimoto T. Housework, paid work, and depression among husbands and wives. J Health Soc Behav. 1994;35:179-91.

37. Lee S, Colditz G, Berkman L, Kawachi I. Caregiving to children and grandchildren and risk of coronary heart disease in women. Am J Public Health. 2003:93:1939-44

38. Matthews S, Power C. Socio-economic gradients in psychological distress: a focus on women, social roles and work-home characteristics. Soc Sci Med. 2002;54:799-810.

39. Ross CE, Mirowsky J, Goldsteen K. The impact of the family on health: the decade in review. J. Marriage Fam. 1990;52:1059-78.

40. Wagman P, Nordin M, Alfredsson L, Westerholm PJ, Fransson El. Domestic work division and satisfaction in cohabiting adults: associations with life satisfaction and self-rated health. Scand J Occup Ther. 2017;24:24-31.

41. Fuwa M, Tsutsui J. A cross-national comparison of the perceived fairness of the division of household labor. Japanese Journal of Family Sociology. 2010;22:52-63.

42. Ikeda A, Iso H, Toyoshima H, Fujino Y, Mizoue T, Yoshimura T, et al. Marital status and mortality among Japanese men and women: the Japan Collaborative Cohort Study. BMC Public Health. 2007;7:73

43. Moriyama $Y$, Toyokawa S, Kobayashi $Y$, Inoue $K$, Suyama $Y$, Sugimoto $N$, et al. A comparison of lifestyle, mental stress, and medical check-up results betweenTanshin-funin workers and workers living with their families. San Ei Shi. 2012;54:22-8.

44. Tsutsui J. Josei no roudou sanka to seibetsu bungyo. J J Labour Stud. 2014;648:70-83

45. Floderus B, Hagman M, Aronsson G, Marklund S, Wikman A. Work status, work hours and health in women with and without children. Occup Environ Med. 2009;66:704-10.

46. Chatani $Y$, Nomura K, Horie S, Takemoto K, Takeuchi M, Sasamori Y, et al. Effects of gaps in priorities between ideal and real lives on psychological burnout among academic faculty members at a medical university in Japan: a cross-sectional study. Environ Health Prev Med. 2017;22:32.

47. Savage S, Bailey S. The impact of caring on caregivers' mental health: a review of the literature. Aust Health Rev. 2004;27:111-7.

48. Saijo Y, Chiba S, Yoshioka E, Kawanishi Y, Nakagi Y, Itoh T, et al. Effects of work burden, job strain and support on depressive symptoms and burnout among Japanese physicians. Int J Occup Med Environ Health. 2014;27:980-92.

49. Ministry of Internal Affairs and Communications. Labour Force Survey, 2018. https://www.e-stat.go.jp/stat-search/files?page=1\&layout=datalist\&toukei=002 $00531 \&$ tstat $=000000110001 \&$ cycle $=7 \&$ year $=20180 \&$ month $=0 \&$ tclass $1=000001$ 040276\&tclass2 $=000001040282 \&$ result_back $=1$ (Accessed on 29 Oct 2019)

50. Nomura K, Karita K, Araki A, Nishioka E, Muto G, Iwai-Shimada M, et al. For making a declaration of countermeasures against the falling birth rate from the Japanese Society for Hygiene: summary of discussion in the working group on academic research strategy against an aging society with low birth rate. Environ Health Prev Med. 2019;24:14.

51. Carlson DS, Kacmar KM, Williams $\sqcup$. Construction and initial validation of a multidimensional measure of work-family conflict. J Vocat Behav. 2000;56:249-76.

52. Mesmer-Magnus JR, Viswesvaran C. Convergence between measures of work-to-family and family-to-work conflict: a meta-analytic examination. J Vocat Behav. 2005;67:215-32.

53. Leineweber C, Baltzer M, Magnusson Hanson LL, Westerlund H. Work-family conflict and health in Swedish working women and men: a 2-year prospective analysis (the SLOSH study). Eur J Public Health. 2012;23:710-6.

\section{Publisher's Note}

Springer Nature remains neutral with regard to jurisdictional claims in published maps and institutional affiliations. 